\title{
The Burden of Post-Thrombotic Syndrome in a Long- Term Retrospective Cohort in Northern Portugal
}

\section{O Impacto a Longo Prazo da Síndrome Pós-Trombótica Numa Coorte Retrospetiva no Norte de Portugal}

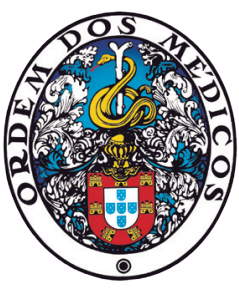

Inês MENDES-ANDRADE ${ }^{1,2, *}$, Marina DIAS-NETO $\rrbracket^{3,4, *}$, João ROCHA-NEVES ${ }^{5,6}$, Armando MANSILHA ${ }^{3,4}$
Acta Med Port 2021 Jan;34(1):35-43 - $\underline{\text { https://doi.org/10.20344/amp.13567 }}$

\section{ABSTRACT}

Introduction: Post-thrombotic syndrome is a frequent and disabling complication of deep venous thrombosis. Its incidence is not described in the Portuguese population. The objective of this study is to report the incidence and severity of post-thrombotic syndrome after the initial episode of deep venous thrombosis.

Material and Methods: This is an observational, unicentric, retrospective cohort of patients who had a first episode of deep venous thrombosis in the lower limb, documented with duplex ultrasound $(n=101)$. The modified Villalta score was applied by phone interview for the diagnosis and staging of post-thrombotic syndrome. The quality of life of patients was measured with the modified CIVIQ 14 classification.

Results: Median follow-up time was six years (interquartile range 1). Severe post-thrombotic syndrome was present in $27 \%$ of patients and moderate in $33 \%$. Performing physical activity at the time of the interview was associated with lower incidence of post-thrombotic syndrome (relative risk $0.489 ; 95 \%$ confidence interval $=0.320-0.748$ ). Body weight gain after deep venous thrombosis (relative risk 2.188; 95\% confidence interval 1.137 - 4.210) and lower education levels (relative risk 2.005; 95\% confidence interval 1.297 - 3.098 ) were associated positively with post-thrombotic syndrome. Quality of life was $90 \pm 17$ vs $64 \pm 18$ vs $43 \pm 15$ in patients without postthrombotic syndrome, with moderate post-thrombotic syndrome and with severe post-thrombotic syndrome, respectively $(p<0.001)$. Discussion: The long-term incidence of post-thrombotic syndrome in a cohort of patients from Northern Portugal is higher than in other studies and correlates with worse adjusted CIVIQ-14 scores.

Conclusion: Large studies of prospective nature could provide more definitive evidence.

Keywords: Postthrombotic Syndrome; Quality of Life; Venous Insufficiency

\section{RESUMO}

Introdução: A síndrome pós-trombótica é uma complicação frequente da trombose venosa profunda, contudo a incidência em Portugal é desconhecida. O principal objetivo é determinar a incidência e gravidade da síndrome pós-trombótica após primeiro episódio de trombose venosa profunda.

Material e Métodos: Estudo de coorte observacional, unicêntrico e retrospetivo de doentes com primeiro episódio de trombose venosa profunda do membro inferior documentado por eco-doppler $(n=101)$. O score Villalta modificado foi aplicado por entrevista telefónica para diagnóstico e categorização da síndrome pós-trombótica. A qualidade de vida dos pacientes foi avaliada pela classificação CIVIQ -14 ajustada.

Resultados: A mediana do tempo de seguimento foi de seis anos. A síndrome pós-trombótica grave esteve presente em $27 \%$ e moderada em $33 \%$. A prática de atividade física no momento da entrevista esteve associada a uma menor incidência de síndrome pós-trombótica (risco relativo $=0,489$; intervalo de confiança de $95 \%=0,320-0,748$ ). O aumento de peso após trombose venosa profunda (risco relativo = 2,188; intervalo de confiança de $95 \%=1,137-4,210$ ) e menores habilitações literárias (risco relativo = 2,005; intervalo de confiança de $95 \%=1,297-3,098$ ) revelaram associação positiva com síndrome pós-trombótica. A qualidade de vida correlacionou-se com a síndrome pós-trombótica, sendo $90 \pm 17,64 \pm 18$ e $43 \pm 15$ em doentes sem síndrome pós-trombótica, com síndrome pós-trombótica moderada e com síndrome pós-trombótica severa, respetivamente $(p<0,001)$.

Discussão: Nesta coorte de doentes no Norte de Portugal, a incidência a longo prazo da síndrome pós-trombótica é superior a outros estudos e correlaciona-se com piores resultados na classificação CIVIQ-14 ajustada.

Conclusão: Estudos prospetivos são necessários para maior evidência.

Palavras-chave: Insuficiência Venosa; Qualidade de Vida; Síndrome Pós-Trombótica

\section{INTRODUCTION}

Post-thrombotic syndrome (PTS) is the result of the sum of symptoms and signs of chronic venous insufficiency. This complication of deep venous thrombosis (DVT) is associated with lower quality of life and significant rates of morbidity. ${ }^{1}$
The pathogenesis of PTS is not perfectly understood. However, venous hypertension has a major role in the development of PTS. ${ }^{2,3}$ Venous hypertension is due to reflux related to valvular incompetence and/or persistent obstruction. Impaired venous return due to venous hypertension

\footnotetext{
${ }^{*}$ Both authors contributed equally to this paper.

1. Faculty of Medicine. University of Porto. Porto. Portugal.

2. Department of Physical Medicine and Rehabilitation. Centro de Medicina de Reabilitação de Alcoitão. Cascais. Portugal.

3. Department of Surgery and Physiology. Faculdade de Medicina. Universidade do Porto. Porto. Portugal.

4. Cardiovascular Research \& Development Unit. Faculdade de Medicina. Universidade do Porto. Porto. Portugal.

5. Department of Angiology and Vascular Surgery. São João Hospital. Porto. Portugal.

6. Unit of Anatomy. Department of Biomedicine. Faculdade de Medicina. Universidade do Porto. Porto. Portugal.

$\square$ Autor correspondente: Marina Dias-Neto. marina f neto@hotmail.com

Recebido: 09 de fevereiro de 2020 - Aceite: 23 de março de 2020 | Copyright @ Ordem dos Médicos 2021
} 
increases tissue permeability, leads to the development of subcutaneous fibrosis, and, finally, to tissue hypoxia and ulceration, ${ }^{4-6}$ the more severe manifestation of PTS. ${ }^{7,8}$

Although PTS is a manifestation of secondary venous insufficiency, the diagnosis should to be postponed until the end of the acute phase, generally after six months. ${ }^{9}$ The incidence of DVT varies between 43.7 to 145.0 cases per $100000 .{ }^{10,11}$ PTS can develop within a few months to a few years after symptomatic DVT. ${ }^{12-17}$ Furthermore, long term evidence has supported the cumulative incidence of PTS even two decades after DVT diagnosis. ${ }^{14,15}$ Several studies that determined the incidence of PTS revealed its presence in $20 \%$ to $50 \%$ of cases with previous DVT. ${ }^{1}$ The severe form of PTS can develop in $5 \%$ to $10 \%$ of patients. ${ }^{1,15,18}$ Nevertheless, the incidence of PTS in Portugal is unknown. The wide range of reported incidence rates is the result of distinct diagnostic criteria used due to nonexistent gold standard tests to confirm the diagnosis of PTS. In fact, the diagnosis is based on clinical grounds alone. The VillaltaPrandoni scale is specific to the post-thrombotic limb and is a reliable, valid measure of PTS in patients with confirmed DVT. ${ }^{19,20}$ This scale is based on the development of characteristic symptoms and physical signs of chronic venous insufficiency such as hyperpigmentation, redness or edema in a patient with prior DVT. A downside of this scale is the fact that it does not take venous claudication or venous ulcer severity directly into account. ${ }^{20}$

The objectives of the present study were (1) to determine the cumulative incidence of PTS after the first episode of DVT; (2) to characterize PTS severity according to a modified Villalta scale; (3) to determine the contribution of risk factors for the development of PTS; (4) to assess quality of life measured by a validated score (the modified CIVIQ-14), and (5) to estimate recurrence of DVT and its impact on PTS incidence.

\section{MATERIAL AND METHODS}

\section{Study design, patients and methodology}

An observational, retrospective cohort study was conducted in a Portuguese tertiary care university hospital located in the North of the country. Consecutive acute admissions coded with ICD9 codes corresponding to lower limb vein thrombosis from 2008 to March 2012 were selected from the hospital database (see Appendix 1: https://www. actamedicaportuguesa.com/revista/index.php/amp/article/ view/13567/Appendix_01.pdf). Inclusion criteria were a first episode of an ultrasound-documented diagnosis of lower limb DVT, observed by physicians from the Angiology and Vascular Surgery department, in patients with ages comprised between 18 and 80 years.

Patients with a history of prior ipsilateral DVT or acute superficial vein thrombosis were not considered. Patients who met inclusion criteria but were not available to contact, or died before the interview, were not included. Those who did not provide consent to participate, were bedridden, suffered a stroke with walking disability or were unable to understand/answer the questions were also excluded.

\section{Diagnosis of post-thrombotic syndrome and quality of life}

A detailed questionnaire with DVT risk factors, including cardiovascular risk factors, acquired risk factors, hereditary risk factors, and transient risk factors was conducted by a trained and supervised research assistant by telephone interview. Additionally, the information obtained from the phone interview was crosschecked with that of electronic medical records. Body mass index (BMI) was calculated as the ratio between weight and square of the height (and expressed in $\mathrm{kg} / \mathrm{m}^{2}$ ). In the telephone interview, compliance to DVT treatment and recurrence of DVT was also questioned about.

In this study, the Villalta scale was designed with the purpose of being used in the telephone interview (Appendix 2: https://www.actamedicaportuguesa.com/revista/index. php/amp/article/view/13567/Appendix_02.pdf) as previously performed. ${ }^{12,21}$ PTS was measured by asking about five symptoms and four patient-reported signs related to lower limb venous disease. PTS was defined as absent with a post-thrombotic score between 0 and 3 points. PTS was considered moderate in patients with a score between 4 and 6 points and severe with a score equal to or higher than 7 , or in the presence of a venous ulcer. ${ }^{21}$ This post thrombotic score revealed an excellent correlation with the Villalta scale, with a kappa coefficient of 0.88 [95\% confidence interval $(\mathrm{Cl}) 0.79-0.96] .{ }^{21}$ The Villalta scale was also associated with quality of life scores (QoL). ${ }^{22,23}$

\section{Impact in quality of life}

The repercussion of the PTS in QoL was measured by a specific tool designed for chronic venous disease - the 14 items Chronic Venous Insufficiency Quality of Life Questionnaire (CIVIQ-14) score, validated for the Portuguese language. The 14 items covered three dimensions: Pain, Physical, and Psychological (Appendix 2: https://www.actamedicaportuguesa.com/revista/index.php/amp/article/ view/13567/Appendix_02.pdf). ${ }^{24}$

\section{Ethics}

The study protocol (protocol number 266-17) was approved by the Ethics Committee for Clinical Research of São João Hospital Center, Porto, Portugal, and informed consent was obtained from all participants.

\section{Statistical analysis}

Discrete variables were expressed as percentages. Continuous variables were expressed as mean and standard deviation or as median, interquartile range (IQR), respectively, if normality may or may not be assumed. Comparisons of continuous or categorical variables were performed through Student's $t$-test, Mann-Whitney $U$ test, chi square or Fisher's test, when applicable. Relative risk (RR) and $95 \% \mathrm{Cl}$ were computed to assess the effect of different exposures in the outcome (PTS). Statistical analysis was performed with SPSS version 24.0.0.0. A $p$ value $<0.05$ was considered statistically significant. 


\section{RESULTS}

Among the 349 candidate patients, 181 were unreachable by phone call, 44 died before the beginning of the study, six refused to participate and 17 did not meet inclusion criteria (Fig. 1).

Excluded patients due to inability of contact or refusal to participate were compared with included patients in terms of age, gender, DVT anatomic location and affected side. These excluded patients were significantly older (median (IQR) of 58 (33) vs 48 (23), p < 0.001) and presented more often DVT with iliac involvement [87 (38) vs 22 (22), $p=0.006$ ] - Appendix 3 (see Appendix 3: https://www.actamedicaportuguesa.com/revista/index.php/amp/article/ view/13567/Appendix_03.pdf).

\section{PTS incidence}

This retrospective cohort had a median follow-up of 6 (IQR 5 - 7) years. The incidence of PTS was $60 \%(95 \% \mathrm{Cl}$ $=50 \%-69 \%$ ), being moderate in $33 \%$ and severe in $27 \%$. Out of all patients with five years of follow-up, $58 \%$ had a diagnosis of PTS. Ouf of all patients with six years of follow up, $69 \%$ had PTS and out of all patients with more than seven years of follow-up, $54 \%$ of patients had PTS.

\section{PTS severity}

The absolute frequency of PTS symptoms and signs reported by 101 patients is directly related with the $\mathrm{mVS}$ (Fig. 2). The most recurrent symptom mentioned was heaviness of leg by 52 (86 \%) patients with PTS. In contrast, in patients without PTS, the most frequent symptom was spontaneous pain in the calf, reported by 11 patients. All patients categorized as having severe PTS had heaviness of the leg. Three symptoms were present in $96 \%$ of patients with severe PTS including spontaneous pain in calf, spontaneous pain while standing and pain worsening during the day. Swelling of the foot or calf was the most reported sign, with $51(85 \%)$ patients with PTS and $16(39 \%)$ without PTS.

\section{PTS risk factors}

Patients were divided according to mVS score in those with and without PTS. The demographic and clinical characteristics of patients are described in Table 1. Among patients with PTS, there were $43(72 \%)$ women, with a median age of 46 (IQR 27) years at the time of the diagnosis of DVT. Among patients without PTS, 22 (54\%) were women. There was no consistent association between sex or age and PTS ( $p=0.064$ and $p=0.660$, respectively).

Baseline BMI at the time of the DVT did not differ between patients with and without PTS (Table 1). However, patients who had elevated BMI after DVT doubled the risk of getting PTS (RR 2.188; 95\% Cl 1.137 - 4.210) - Figs. 3A and $3 \mathrm{~B}$.

Likewise, the proportion of patients who were doing sports and the frequency of physical activity at baseline were not different between patients with and without PTS ( $15 \%$ vs $8 \%, p=0.297$ with a median of 0 times per week in both groups, $p=0.212$ ). On the other hand, patients who engaged in physical activity regularly at the time of the interview had a reduced risk of developing PTS (RR 0.489; $95 \% \mathrm{Cl} 0.320$ - 0.748). Patients with PTS reported a median and IQR of 0 times per week while patients without PTS reported a median of 0 and IQR of 2 times per week ( $p=$ 0.011).

The proportions of patients in each of the four education levels were not homogenous among patients with and without PTS ( $p=0.033$ ) (Table 1). The risk of developing DVT among patients who studied only in elementary school or high school was two times as high as the risk of those who had a university degree (RR 2.005; 95\% Cl 1.297 - 3.098).

There were no differences in the proportion of patients

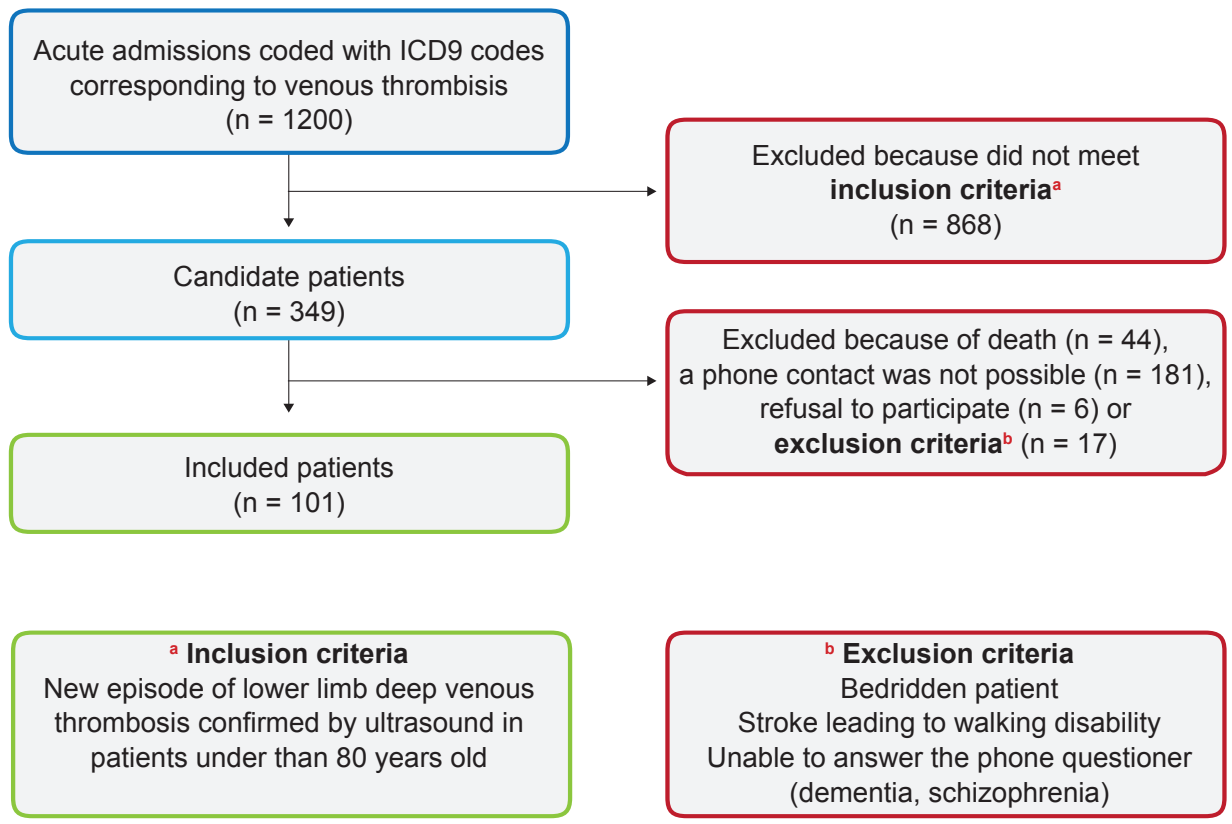

Figure 1 - Flow diagram of patients in the study 


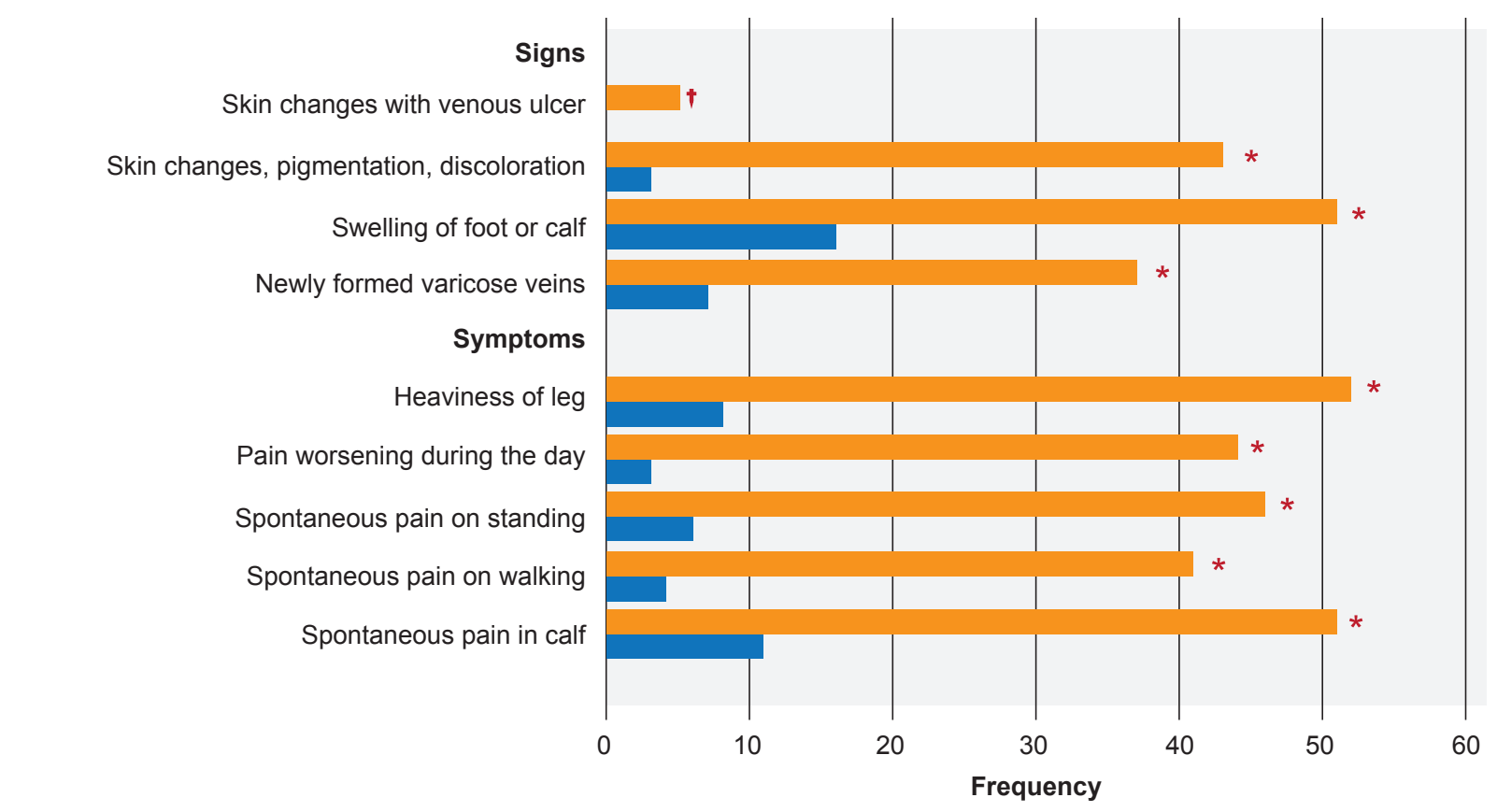

- Presence of PTS

- Absence of PTS

Figure 2 - Post-thrombotic symptoms and signs

$*: p<0.001 ; \uparrow: p=0.078$

with a prior episode of contralateral superficial venous thrombosis nor of previous contralateral DVT between PTS and non-PTS patients $(p=0.079$ and $p=0.406$, respectively).

Most of the variables considered in the Caprini DVT risk score ${ }^{25}$ did not show significant association with PTS. Even though DVT, in the context of surgery, was associated with PTS, the corresponding RR was 2.244 (95\% Cl 0.993 - 5.073). Hereditary risk factors including thrombophilia did not achieve significant differences, and neither did cardiovascular risk factors.

The DVT involved the popliteal sector more often $(64 \%$, $n=65)$, followed by the femoral $(54 \%, n=54)$, the iliac $(22 \%, n=22)$ and the gemelar veins $(20 \%, n=20)($ Appendix 3: https://www.actamedicaportuguesa.com/revista/ index.php/amp/article/view/13567/Appendix_03.pdf). Patients with and without PTS presented no differences regarding the DVT site nor the number of anatomical sectors affected. Only one episode of pulmonary embolism was identified, occurring in the group of patients that later developed PTS ( $p=1.000$ ) (Appendix 4:: https://www.actamedicaportuguesa.com/revista/index.php/amp/article/ view/13567/Appendix_04.pdf).

The treatment received for DVT was similar in both subgroups. Patients were treated initially with low molecular weight heparin (enoxaparin was used in the majority of the cases) in combination with oral anticoagulation; no differences were shown in the duration of anticoagulation therapy. Despite all the patients being prescribed elastic stockings, only $83 \%(n=84)$ of patients used them during a median (IRQ) of six (12) months and throughout a duration of 12 (14) hours per day (Appendix 4:: https://www. actamedicaportuguesa.com/revista/index.php/amp/article/
view/13567/Appendix_04.pdf).

\section{Quality of life}

The CIVIQ-14 analysis is represented in Fig. 4. The scores in each of the three dimensions were higher in patients with PTS compared to patients without PTS ( $p<$ 0.001). The 'Pain' dimension is divided in subcategories (scale from 1 to 5), according to symptoms occurring in the past four weeks. In the 'Sleeping poorly' dimension, while the median of the reported score in patients without PTS was 1 (never), patients with PTS reached 2 (rare impact). The difference of reported score between groups was higher in the other two subcategories: 'Pain in the legs' and 'impairment at work'. In patients with PTS, the median of answered questions was 4 (considerable trouble/pain), whereas nonPTS patients had a median score of 1 (no trouble or no pain).

The highest CIVIQ-14 scores were seen in patients without PTS; the score yielded significantly lower results in patients with moderate PTS and the lowest results in patients with severe PTS $(p<0.001)$ - Fig. 5.

\section{Recurrence of DVT}

Finally, differences in recurrence of DVT or of venous thromboembolic events in general were also not detected in patients with versus patients without PTS (Appendix 5: : https://www.actamedicaportuguesa.com/revista/index.php/ amp/article/view/13567/Appendix_05.pdf).

\section{DISCUSSION}

This is a retrospective cohort of patients that presented a first episode of DVT in the lower limb, with a median follow-up time of six years. This single report on incidence 
Table 1 - Demographic and clinical characteristics of 101 patients with an initial deep venous thrombosis of the lower limb

\begin{tabular}{|c|c|c|c|c|c|}
\hline \multicolumn{2}{|l|}{ 20 } & $\begin{array}{l}\text { Without PTS } \\
\quad(n=41)\end{array}$ & $\begin{array}{c}\text { With PTS } \\
(n=60)\end{array}$ & $\begin{array}{c}\text { Total } \\
(n=101)\end{array}$ & $p$ \\
\hline \multicolumn{2}{|l|}{ Gender (women), n (\%) } & $22(54)$ & $43(72)$ & $65(64)$ & 0.064 \\
\hline \multicolumn{2}{|c|}{ Age (years), median (IQR) } & $49(20)$ & $46(27)$ & $48(23)$ & 0.660 \\
\hline \multirow{2}{*}{$\begin{array}{l}\text { BMI }\left(\mathrm{kg} / \mathrm{m}^{2}\right), \text { median } \\
(\mathrm{IQR})\end{array}$} & At onset of DVP & $26(6)$ & $27(5)$ & $26(6)$ & 0.309 \\
\hline & Actual & $25(5)$ & $28(7)$ & $27(5)$ & 0.039 \\
\hline \multirow{2}{*}{$\begin{array}{l}\text { Physical activity (yes/ } \\
\text { no), n (\%)) }\end{array}$} & At onset of DVP & $6(15)$ & $5(8)$ & $11(11)$ & 0.297 \\
\hline & Actual & $12(29)$ & $5(8)$ & $17(17)$ & 0.006 \\
\hline \multirow{2}{*}{$\begin{array}{l}\text { Frequency of physical } \\
\text { activity (days per } \\
\text { week), median (IQR) }\end{array}$} & At onset of DVP & $0(0)$ & $0(0)$ & $0(0)$ & 0.212 \\
\hline & Actual & $0(2)$ & $0(0)$ & $0(0)$ & 0.011 \\
\hline \multirow{4}{*}{ Education, n (\%) } & Elementary school & $27(66)$ & $47(78)$ & $74(73)$ & 0.033 \\
\hline & High School & $4(10)$ & $9(15)$ & $13(13)$ & \\
\hline & Academic Degree & $7(17)$ & $3(5)$ & $10(10)$ & \\
\hline & Masters or PhD Degree & $3(7)$ & $1(2)$ & $4(4)$ & \\
\hline \multicolumn{6}{|c|}{ Cardiovascular risk factors } \\
\hline \multicolumn{2}{|c|}{ HTA, n (\%) } & $15(37)$ & $29(48)$ & $44(44)$ & 0.242 \\
\hline \multicolumn{2}{|l|}{ Dyslipidemia, n (\%) } & $18(44)$ & $25(42)$ & $43(43)$ & 0.823 \\
\hline \multicolumn{2}{|l|}{$\mathrm{DM}, \mathrm{n}(\%)$} & $6(15)$ & $7(12)$ & $13(13)$ & 0.662 \\
\hline \multirow[t]{4}{*}{ Tobacco, n (\%) } & Never & $23(55)$ & $44(73)$ & $67(66)$ & 0.312 \\
\hline & Without smoking (> 10 years) & $8(20)$ & $5(8)$ & $13(13)$ & \\
\hline & Without smoking ( $<10$ years $)$ & $6(15)$ & $4(7)$ & $10(10)$ & \\
\hline & Active smoker & $4(10)$ & $7(12)$ & $11(11)$ & \\
\hline \multicolumn{2}{|c|}{ Tobacco (pack-year units), median (IQR) } & $10(54)$ & $15(19)$ & $10(25)$ & 0.794 \\
\hline \multicolumn{6}{|c|}{ Acquired risk factors } \\
\hline \multicolumn{2}{|l|}{ CAD, n $(\%)$} & $4(10)$ & $7(12)$ & $11(11)$ & 1.000 \\
\hline \multicolumn{2}{|c|}{ Arrhythmia, n (\%) } & 0 & $4(7)$ & $4(4)$ & 0.144 \\
\hline \multicolumn{2}{|c|}{ Chronic kidney disease, $\mathrm{n}(\%)$} & $2(5)$ & $5(8)$ & $7(7)$ & 0.698 \\
\hline \multicolumn{2}{|c|}{ Lung diseases, $\mathrm{n}(\%)$} & $1(2)$ & $3(5)$ & $4(4)$ & 0.645 \\
\hline \multicolumn{2}{|l|}{$\mathrm{IBD}, \mathrm{n}(\%)$} & 0 & $1(2)$ & $1(1)$ & 1.000 \\
\hline \multicolumn{2}{|l|}{ Cancer, n (\%) } & $6(15)$ & $8(13)$ & $14(14)$ & 0.853 \\
\hline $\mathrm{PE}, \mathrm{n}(\%)$ & & 0 & $1(2)$ & $1(1)$ & 1.000 \\
\hline SVT, n (\%) & Total & $\mathrm{n}=0$ & $n=6$ & $\mathrm{n}=6$ & 0.079 \\
\hline & Ipsilateral & 0 & $5(8)$ & $5(5)$ & 0.078 \\
\hline & Contralateral & 0 & $1(2)$ & $1(1)$ & 1.000 \\
\hline Contralateral DVT, n (\% & & $1(2)$ & 0 & $1(1)$ & 0.406 \\
\hline Previous thromboembo & lic event, n (\%) & $1(2)$ & $7(12)$ & $8(8)$ & 0.138 \\
\hline APS, n (\%) & & 0 & $2(3)$ & $2(2)$ & 0.513 \\
\hline Lupus, n (\%) & & 0 & $1(2)$ & $1(1)$ & 1.000 \\
\hline Surgery, n (\%) & & $5(12)$ & $19(32)$ & $24(24)$ & 0.024 \\
\hline Trauma, n (\%) & & $3(7)$ & $6(10)$ & $9(9)$ & 0.735 \\
\hline Immobilization $(<72$ ho & urs), n (\%) & $6(15)$ & $6(10)$ & $12(12)$ & 0.480 \\
\hline Immobilization (> 72 ho & urs), n (\%) & $3(7)$ & $14(23)$ & $17(17)$ & 0.056 \\
\hline Hospitalization, n (\%) & & $2(5)$ & $2(3)$ & $4(4)$ & 1.000 \\
\hline Central venous access & n (\%) & $1(2)$ & 0 & $1(1)$ & 0.406 \\
\hline Flight (> 5 hours), n (\% & & $2(5)$ & $1(2)$ & $3(3)$ & 0.565 \\
\hline HT/ Contraceptive meth & od, n (\%) & $11(27)$ & $21(35)$ & $32(32)$ & 0.386 \\
\hline Infection, n (\%) & & $1(2)$ & $2(3)$ & $3(3)$ & 1.000 \\
\hline Hereditary risk factor & & & & & \\
\hline Thrombophilia, n (\%) & & $1(2)$ & $7(12)$ & $8(8)$ & 0.138 \\
\hline Number of mutations, & 1 gene & $1(2)$ & $4(7)$ & $5(5)$ & 0.124 \\
\hline $\mathrm{n}(\%)$ & 2 genes & 0 & $2(3)$ & $2(2)$ & \\
\hline Family History of DVT, & $(\%)$ & $11(27)$ & $22(37)$ & $33(33)$ & 0.301 \\
\hline Family History other Th & rombosis, n (\%) & $5(12)$ & $2(3)$ & $7(7)$ & 0.117 \\
\hline
\end{tabular}

IQR: interquartile range; BMI: body mass index; HTA: arterial hypertension; DM; diabetes mellitus; CAD; coronary artery disease; IBD: inflammatory bowel disease; PE: pulmonary embolism; APS: antiphospholipid antibody syndrome; SVT: superficial venous thrombosis; DVT: deep venous thrombosis. Previous thromboembolic event includes PE + SVT+ DVT; APS: antiphospholipid antibody syndrome; HT: hormone therapy. Thrombophilia was considered if one or more or the following mutations were present: Antithrombin deficiency, Protein C deficiency, Protein S deficiency, Factor V Leiden, Prothrombin gene mutation. Hyperhomocysteinemia, Tetrahydrofolate reductase mutation. 
Without PTS

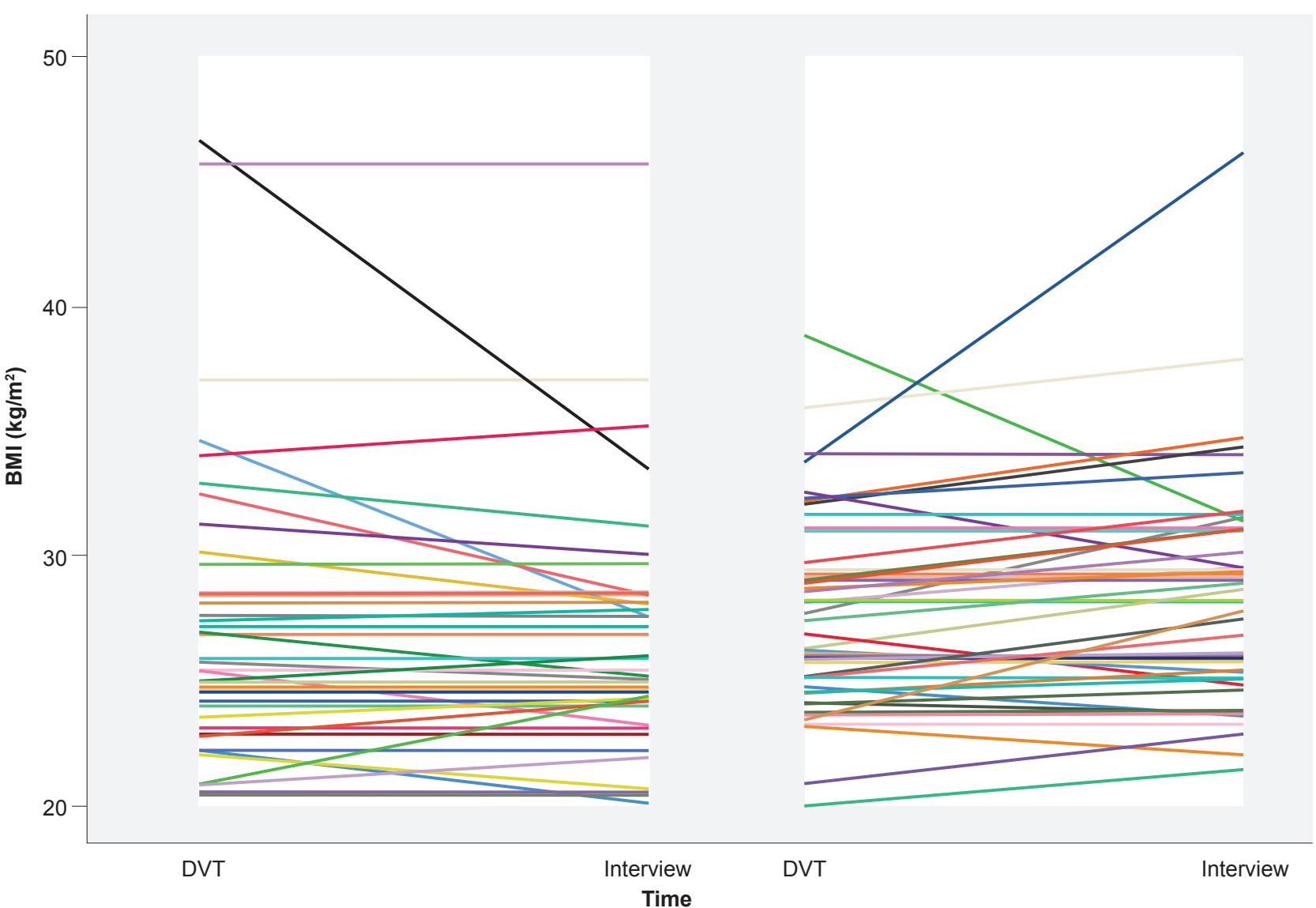

Figure 3A - Spaghetti plot of the body mass index change from the time of the DVT diagnosis to the time of the interview in both PTS and non-PTS patients

of PTS in Northern Portugal showed that the most frequent long-term complication of DVT affects $60 \%$ of patients after DVT, being severe in $27 \%$ and moderate in $33 \%$.

The incidence of PTS found in this study is higher than in other non-Portuguese studies, where PTS incidence ranged from $20 \%$ to $50 \%$ with follow-up time lower than six years. ${ }^{1}$ Notwithstanding, these results are lower than those previously reported in a Portuguese retrospective cohort

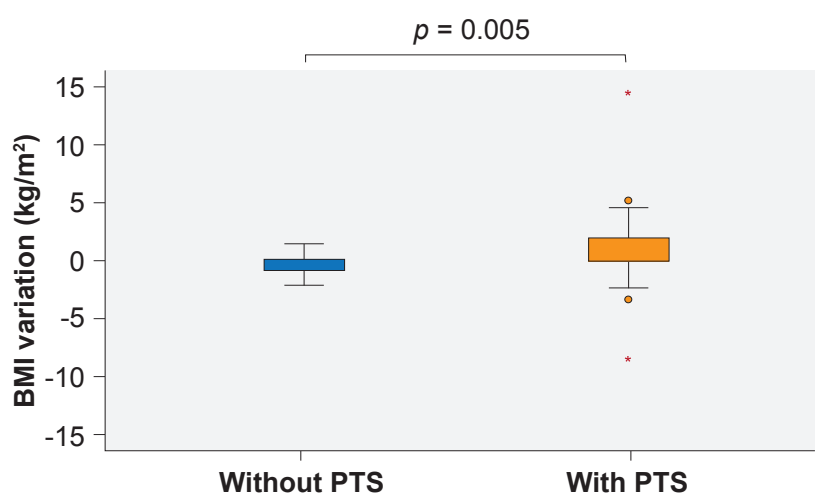

Figure 3B - Box plot of body mass index change (body weight at the time of the interview subtracted by the body weight at the time of the DVT) in both PTS and non-PTS patients *: outlier study, where PTS was found in $89.3 \% .^{26}$ This study included 39 patients with ilio-femoral DVT who were potential candidates for catheter-directed thrombolysis at the time of diagnosis. ${ }^{27}$ The inclusion of DVTs restricted to those affecting the ilio-femoral sector may underlie the disparity in PTS incidence since ilio-femoral DVT is often associated with higher rates of PTS., ${ }^{9,13}$ In fact, in the ATTRACT multicenter randomized trial, pharmacomechanical catheter-directed thrombolysis led to less residual thrombus, and common femoral vein non- compressibility at one month was associated with more PTS, more severe PTS, and worse QOL at 24 months. ${ }^{27}$ In this regard, a direct comparison cannot be performed between the two Portuguese studies. The disparity of PTS incidence with other studies can be caused by methodological differences such as the use of a modified Villalta score and/or due to bias introduced by the number of patients that were not interviewed $(n=187)$ because they were not able to be reached by phone contact or refused to participate.

There is consensus about prognostic factors for recurrent DVT. However, factors that increase the risk of developing PTS are not entirely accurate ${ }^{18}$ and predictive models for PTS are still weak. According to the American Heart Association, risk factors might be divided into factors at the time of DVT diagnosis and those that emerge during 


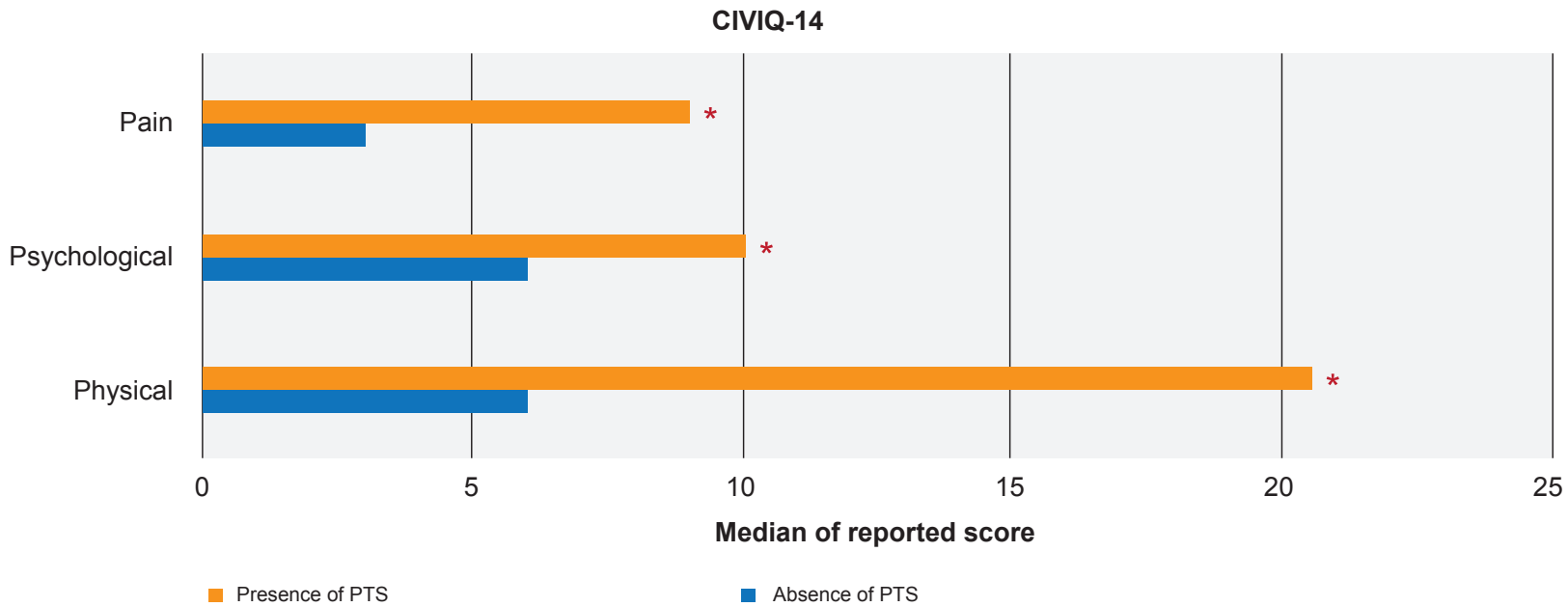

Figure 4 - Chronic Venous Insufficiency Quality of Life Questionnaire (CIVIQ-14) score

*: $p<0.001$; Dimension Pain (minimum score of 3 to maximum score of 15); Dimension Physical (minimum score of 5 to maximum score of 25); Dimension Psychological (minimum score of 6 to maximum score of 30 )

\section{follow-up. ${ }^{28}$}

In our sample, sex and age were not associated with PTS. While gender is not consistently reported as a risk factor for PTS, ${ }^{13,17,21,29}$ an older age is a well-recognized risk factor for PTS. ${ }^{9,30}$ In our study, patients aged over 80 years were excluded due to higher chance of lower mobility as a consequence of osteoarticular problems or stroke and of incapability to answer questions accurately. It is possible that the absence of the age group above 80 years old might be related to the lack of association of PTS with age. Alternatively, the lack of association might be due to an underpowered sample size.

The American Heart Association considered elevated BMI at the time of the DVT ${ }^{13,17,21,31-34}$ as a PTS risk factor. ${ }^{9}$ In this study, patients who had increased BMI after DVT had higher risk of developing PTS. Furthermore, physical activity performed at the time of the interview was less often performed by patients with PTS versus non-PTS. In fact, excess body weight during the years after DVT might increase venous pressure and generate even more reflux in the damaged veins. ${ }^{21}$ It is plausible that weight loss, by decreasing central and intra-abdominal venous pressure, might improve PTS symptoms. ${ }^{35}$ Accordingly, a recent study revealed that lower adiponectin and higher leptin measured three months after DVT, regardless of obesity, can predict PTS, which suggests the involvement of adipokines in PTS ${ }^{36}$ On the other hand, it is also possible that the development of PTS might lead to less physical activity, predisposing to weight gain, which means that inverse causality bias cannot be excluded. Favoring the hypothesis of inverse causality is the finding that exercise in the first month after DVT was not related with an increased risk of PTS two years after DVT. ${ }^{37}$ Further studies with a larger number of patients allowing adjustment for confounders using multivariate analysis are essential to clarify our findings.

Another interesting finding of this study was that patients who only studied until elementary school or high school had a higher incidence of PTS, compared to patients with an academic degree. Patients with higher educational levels might be more aware and perhaps diagnosed and treated earlier for their DVTs. Another possible explanation is that patients with lower education levels have less differentiated jobs that might require longer periods of standing or physical strain. Controlling for all the possible confounding factors affecting this apparent association might be difficult even in a multivariate analysis. For that reason, it is not surprising the lack of a consistent association between level of education and income and PTS or DVT. 14,17,21,38,39

PTS is considered a chronic condition, so QoL should be assessed during a judicious examination. Through the CIVIQ-14 score it was demonstrated that disease specific quality of life was significantly worse in PTS patients in all categories compared to non-PTS patients. ${ }^{18,23}$

This study has some limitations. First, it is a retrospective cohort with its inherent features. Some previously identified risk factors of PTS such as the presence of residual venous obstruction on ultrasound, ${ }^{9}$ as well as persistent leg symptoms one month after acute DVT ${ }^{9}$ could not be addressed because of this. Second, the selection of our sample

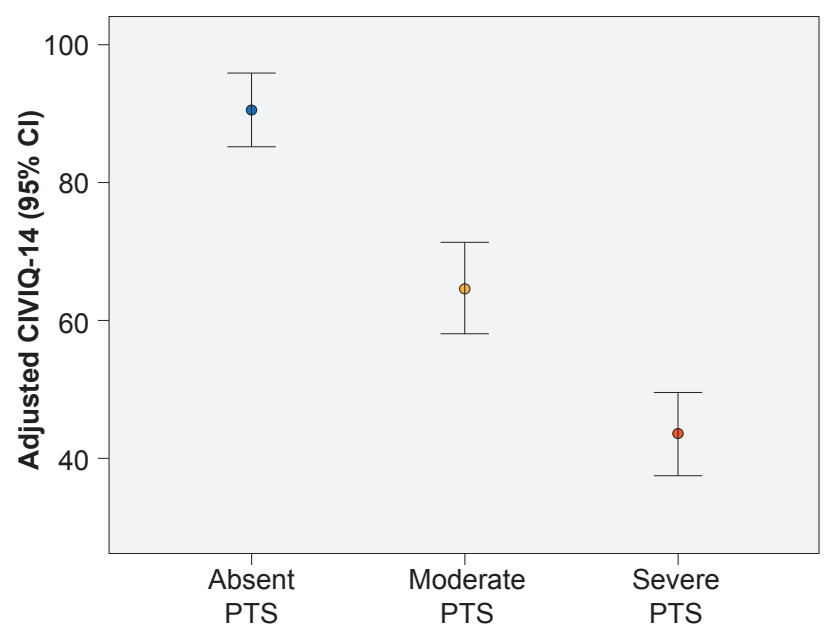

Figure 5 - Error bar of the adjusted CIVIQ-14 classification (95\% confidence interval) in patients with moderate and severe PTS and in patients without PTS, $p=0.001$ 
required the use of a wide range of ICD-9 codes for lower limb venous thrombosis. After this, each patient was selected or excluded all acute admission records were reviewed. Third, after the diagnosis of DVT, most patients do not receive follow-up in the outpatient consultation of a hospital but instead at the respective primary health care center throughout Northern Portugal. Moreover, a high number of patients enrolled in the study were first admissions into the database of the hospital and the DVT episode remained the unique episode in the database. As a consequence, 187 patients eligible for this study were excluded due to unavailable/incorrect contacts or refusal to participate. In order to overcome this limitation, sensitivity analyses were performed. Patients excluded due to unavailable/incorrect contacts or refusal to participate were older and had a more frequent involvement of the iliac sector. Therefore, the high incidence of PTS yielded in this study might be underestimated, since age and iliac involvement are two well-known risk factors for PTS. This weakness remains the most important limitation of this study, as patients might differ in many other aspects not assessed in the comparison we performed and that may have an impact in PTS, such as belonging to different socioeconomic groups, which has been associated with worse outcomes when facing illness. Fourth, this unexpected difficulty in contacting patients resulted in a smaller than anticipated sample size, although external validity is probably not compromised. We believe that some important risk factors of PTS such as the extension, size and location of DVT ${ }^{9,13}$ or recurrent ipsilateral $\mathrm{DVT}^{28}$ were not confirmed in the present study due to sample limitations. Fifth, the use of a mVS by phone interview could influence the results. However, this modified scale was applied in a previous

\section{REFERENCES}

1. Kahn SR. The post-thrombotic syndrome. Hematology Am Soc Hematol Educ Program. 2016;2016:413-8.

2. Franzeck UK, Schalch I, Jager KA, Schneider E, Grimm J, Bollinger A. Prospective 12-year follow-up study of clinical and hemodynamic sequelae after deep vein thrombosis in low-risk patients (Zurich study). Circulation. 1996;93:74-9.

3. Bergan JJ, Schmid-Schonbein GW, Smith PD, Nicolaides AN, Boisseau MR, Eklof B. Chronic venous disease. N Engl J Med. 2006;355:488-98.

4. Nicolaides AN, Hussein MK, Szendro G, Christopoulos D, Vasdekis S, Clarke $\mathrm{H}$. The relation of venous ulceration with ambulatory venous pressure measurements. J Vasc Surg. 1993;17:414-9.

5. Araki CT, Back TL, Padberg FT, Thompson PN, Jamil Z, Lee BC, et al. The significance of calf muscle pump function in venous ulceration. J Vasc Surg. 1994;20:872-7.

6. Welkie JF, Comerota AJ, Katz ML, Aldridge SC, Kerr RP, White JV. Hemodynamic deterioration in chronic venous disease. J Vasc Surg. 1992;16:733-40.

7. Prandoni P, Kahn SR. Post-thrombotic syndrome: prevalence, prognostication and need for progress. Br J Haematol. 2009;145:28695.

8. Vedantham S. Valvular dysfunction and venous obstruction in the postthrombotic syndrome. Thromb Res. 2009;123:S62-5.

9. Kahn SR, Comerota AJ, Cushman M, Evans NS, Ginsberg JS, Goldenberg NA, et al. The postthrombotic syndrome: evidence-based prevention, diagnosis, and treatment strategies: a scientific statement from the American Heart Association. Circulation. 2014;130:1636-61.

10. Nordstrom M, Lindblad B, Bergqvist D, Kjellstrom T. A prospective study of the incidence of deep-vein thrombosis within a defined urban population. J Intern Med. 1992;232:155-60.

11. Anderson FA Jr., Wheeler HB, Goldberg RJ, Hosmer DW, Patwardhan large population-based case-control study, which revealed an excellent relationship with the Villalta scale. ${ }^{21}$

\section{CONCLUSION}

This study is a cohort of patients with DVT representative of Northern Portugal with a median follow-up time of 72 months. About $60 \%$ of patients demonstrated PTS, that was correlated with worse adjusted CIVIQ-14 scores.

Further studies, namely of prospective nature, are essential to demonstrate the impact of risk factor modification such as weight reduction or exercise in preventing or improving the prognosis of PTS.

\section{PROTECTION OF HUMAN SUBJECTS}

The authors declare that the procedures were followed according to the regulations established by the Clinical Research and Ethics Committee and to the Helsinki Declaration issued by World Medical Association.

\section{CONFIDENTIALITY OF DATA}

The authors declare having followed the protocols in use at their working center regarding patients' data publication.

\section{CONFLICTS OF INTEREST}

The authors report no conflict of interest that might interfere in the present study.

\section{FINANCIAL SOURCES No funding was received for this research.}

No funds were required to perform this study.

NA, Jovanovic B, et al. A population-based perspective of the hospital incidence and case-fatality rates of deep vein thrombosis and pulmonary embolism. The Worcester DVT Study. Arch Intern Med. 1991;151:933-8.

12. Prandoni P, Lensing AW, Cogo A, Cuppini S, Villalta S, Carta M, et al. The long-term clinical course of acute deep venous thrombosis. Ann Intern Med. 1996;125:1-7.

13. Kahn SR, Shrier I, Julian JA, Ducruet T, Arsenault L, Miron MJ, et al. Determinants and time course of the postthrombotic syndrome after acute deep venous thrombosis. Ann Intern Med. 2008;149:698-707.

14. Aschwanden M, Jeanneret C, Koller MT, Thalhammer C, Bucher HC, Jaeger KA. Effect of prolonged treatment with compression stockings to prevent post-thrombotic sequelae: a randomized controlled trial. J Vasc Surg. 2008;47:1015-21.

15. Schulman S, Lindmarker P, Holmstrom M, Lärfars G, Carlsson A, Nicol $\mathrm{P}$, et al. Post-thrombotic syndrome, recurrence, and death 10 years after the first episode of venous thromboembolism treated with warfarin for 6 weeks or 6 months. J Thromb Haemost. 2006;4:734-42.

16. Ginsberg JS, Hirsh J, Julian J, Vander LaandeVries M, Magier D, MacKinnon B, et al. Prevention and treatment of postphlebitic syndrome: results of a 3-part study. Arch Intern Med. 2001;161:2105-9.

17. Stain M, Schonauer V, Minar E, Bialonczyk C, Hirschl M, Weltermann A, et al. The post-thrombotic syndrome: risk factors and impact on the course of thrombotic disease. J Thromb Haemost. 2005;3:2671-6.

18. Ordi J, Salmeron L, Acosta F, Camacho I, Marin N. Study of prognostic factors and prevalence of post-thrombotic syndrome in patients with deep vein thrombosis in Spain. Med Clin. 2016;146:49-54.

19. Kahn SR. Measurement properties of the Villalta scale to define and classify the severity of the post-thrombotic syndrome. J Thromb Haemost. 2009;7:884-8.

20. Wittens C, Davies AH, Baekgaard N, Broholm R, Cavezzi A, Chastanet 
S, et al. Editor's Choice - Management of Chronic Venous Disease: Clinical Practice Guidelines of the European Society for Vascular Surgery (ESVS). Eur J Vasc Endovasc Surg. 2015;49:678-737.

21. Tick LW, Kramer MH, Rosendaal FR, Faber WR, Doggen CJ. Risk factors for post-thrombotic syndrome in patients with a first deep venous thrombosis. J Thromb Haemost. 2008;6:2075-81.

22. Kahn SR, Shbaklo H, Lamping DL, Holcroft CA, Shrier I, Miron MJ, et al. Determinants of health-related quality of life during the 2 years following deep vein thrombosis. J Thromb Haemost. 2008;6:1105-12.

23. Kahn SR, Hirsch A, Shrier I. Effect of postthrombotic syndrome on health-related quality of life after deep venous thrombosis. Arch Intern Med. 2002;162:1144-8.

24. Launois R, Le Moine JG, Lozano FS, Mansilha A. Construction and international validation of CIVIQ-14 (a short form of CIVIQ-20), a new questionnaire with a stable factorial structure. Qual Life Res. 2012;21:1051-8.

25. Caprini JA. Risk assessment as a guide for the prevention of the many faces of venous thromboembolism. Am J Surg. 2010;199:S3-10.

26. Maia M, Vidoedo J, Pinto JA. Síndrome pós-trombótica e qualidade de vida em doentes com thromboses venosa ilio-femoral. Revista da Sociedade Portuguesa de Angiologia e Cirurgia Vascular. 2014;10:1739.

27. Weinberg I, Vedantham S, Salter A, Hadley G, Al-Hammadi N, Kearon C, et al. Relationships between the use of pharmacomechanical catheterdirected thrombolysis, sonographic findings, and clinical outcomes in patients with acute proximal DVT: results from the ATTRACT Multicenter Randomized Trial. Vasc Med. 2019;24:442-51.

28. Baldwin MJ, Moore HM, Rudarakanchana N, Gohel M, Davies AH. Post-thrombotic syndrome: a clinical review. J Thromb Haemost. 2013;11:795-805.

29. Tick LW, Doggen CJ, Rosendaal FR, Faber WR, Bousema MT, Mackaay $\mathrm{AJ}$, et al. Predictors of the post-thrombotic syndrome with non-invasive venous examinations in patients 6 weeks after a first episode of deep vein thrombosis. J Thromb Haemost. 2010;8:2685-92.

30. Wik HS, Jacobsen AF, Sandvik L, Sandset PM. Long-term impact of pregnancy-related venous thrombosis on quality-of-life, general health and functioning: results of a cross-sectional, case-control study. BMJ Open. 2012;2:e002048.

31. Galanaud JP, Holcroft CA, Rodger MA, Kovacs MJ, Betancourt MT, Wells PS, et al. Predictors of post-thrombotic syndrome in a population with a first deep vein thrombosis and no primary venous insufficiency. J Thromb Haemost. 2013;11:474-80.

32. Kahn SR, Kearon C, Julian JA, Mackinnon B, Kovacs MJ, Wells P, et al Predictors of the post-thrombotic syndrome during long-term treatment of proximal deep vein thrombosis. J Thromb Haemost. 2005;3:718-23.

33. van Dongen CJ, Prandoni P, Frulla M, Marchiori A, Prins $M H$, Hutten BA. Relation between quality of anticoagulant treatment and the development of the postthrombotic syndrome. J Thromb Haemost. 2005;3:939-42.

34. Ageno W, Piantanida E, Dentali F, Steidl L, Mera V, Squizzato A, et al. Body mass index is associated with the development of the postthrombotic syndrome. Thromb Haemost. 2003;89:305-9.

35. Eberhardt RT, Raffetto JD. Chronic venous insufficiency. Circulation. 2014;130:333-46.

36. Sandra M, Joanna C, Elżbieta B, Anetta U. Elevated leptin and decreased adiponectin independently predict the post-thrombotic syndrome in obese and non-obese patients. Sci Rep. 2018:6938.

37. Shrier I, Kahn SR, Steele RJ. Effect of early physical activity on longterm outcome after venous thrombosis. Clin J Sport Med. 2009;19:48793.

38. Persson LM, Lapidus LJ, Larfars G, Rosfors S. Asymptomatic deep venous thrombosis is associated with a low risk of post-thrombotic syndrome. Eur J Vasc Endovasc Surg. 2009;38:229-33.

39. Spiezia L, Tormene D, Pesavento R, Salmaso L, Simioni P, Prandoni P. Thrombophilia as a predictor of persistent residual vein thrombosis. Haematologica. 2008;93:479-80. 